\title{
AUGMENTED REALITY AND TRAINING NEEDS FROM A WIDER EUROPEAN CONTEXT
}

\author{
RICHTEREK Lukáš - ŘÍHA Jan, CZ
}

\begin{abstract}
The report of AROMA project (AROMA project consortium, 2018) summarizes a detailed study performed within project partner countries (Belgium, Czech Republic, Greece, Malta, Romania, Spain and Sweden) aimed at identifying the training needs connected with augmented reality technology (AR) and entrepreneurial skills and mapping an awareness about the AR technology. For the project, the research also serves as a first step to identify gaps that need to be addressed to offer a holistic syllabus integrating AR with selected skills and competencies.
\end{abstract}

Key words: augmented reality, competencies for entrepreneurship, vocational education and training

\section{ROZŠÍŘENÁ REALITA A ODBORNÁ PŘÍPRAVA V ŠIRŠÍM EVROPSKÉM KONTEXTU}

\begin{abstract}
Abstrakt
Zpráva projektu AROMA (AROMA project consortium, 2018) shrnuje studii provedenou v partnerských zemích projektu (Belgie, Česká republika, Řecko, Malta, Rumunsko, Španělsko a Švédsko) s cílem identifikovat vzdělávací potřeby spojené s technologií rozšířené reality (AR) i s rozvojem dovedností a kompetencí k podnikání a zmapovat povědomí o technologii AR. Pro projekt slouží šetření také jako první krok k identifikaci mezer a problémových míst, které by mohl pokrýt kurz integrující AR s vybranými dovednostmi a kompetencemi.
\end{abstract}

Klíčová slova: rozšířená realita, kompetence pro podnikání, odborné vzdělávání a příprava

\section{Introduction}

The Erasmus+ KA2 AROMA project (Digital Training Toolbox for Entrepreneurial Training in Augmented Reality, No. 2017-1-CZ01-KA202-035560) is motivated by the EU's Entrepreneurship 2020 Action Plan. The digital world is developing novel technologies that can offer a range of opportunities for businesses in the knowledge-based economy and for education. These trends reflect a need that vocational education (VET) training in appropriate skills should also focus on exploiting digital technologies to help foster new business opportunities and raise general awareness about the potential of some digital technologies, namely the AR, which can help to enhance key competencies such as digital skills, entrepreneurship, lifelong learning, decision making etc. The AR technology itself has a potential that can be exploited in various fields and many training and educational activities - see also e.g. (Akçayır \& Akçayır, 2017; Chang \& Hwang, 2018; Chen, \& Wang, 2015; Fuchsova \& Korenova, 2019; Ibáñez \& Delgado-Kloos, 2018; Chen \& Wang, 2015; Lamanauskas, 2008; Lincoln, J., 2018; Yip, J. et al., 2018). Therefore, it can be interesting and important to map the overall awareness about the technology among VET trainers, its possible exploitation for the training in various contexts and if or how it could help to develop some selected competencies closely connected with entrepreneurship.

\section{Methodology of research}

The survey had two essential parts. The first one was an online anonymous questionnaire including 15 questions grouped into 3 sections: respondent background, knowledge of the AR technology and 
Figure 1: The importance of the EU key competencies

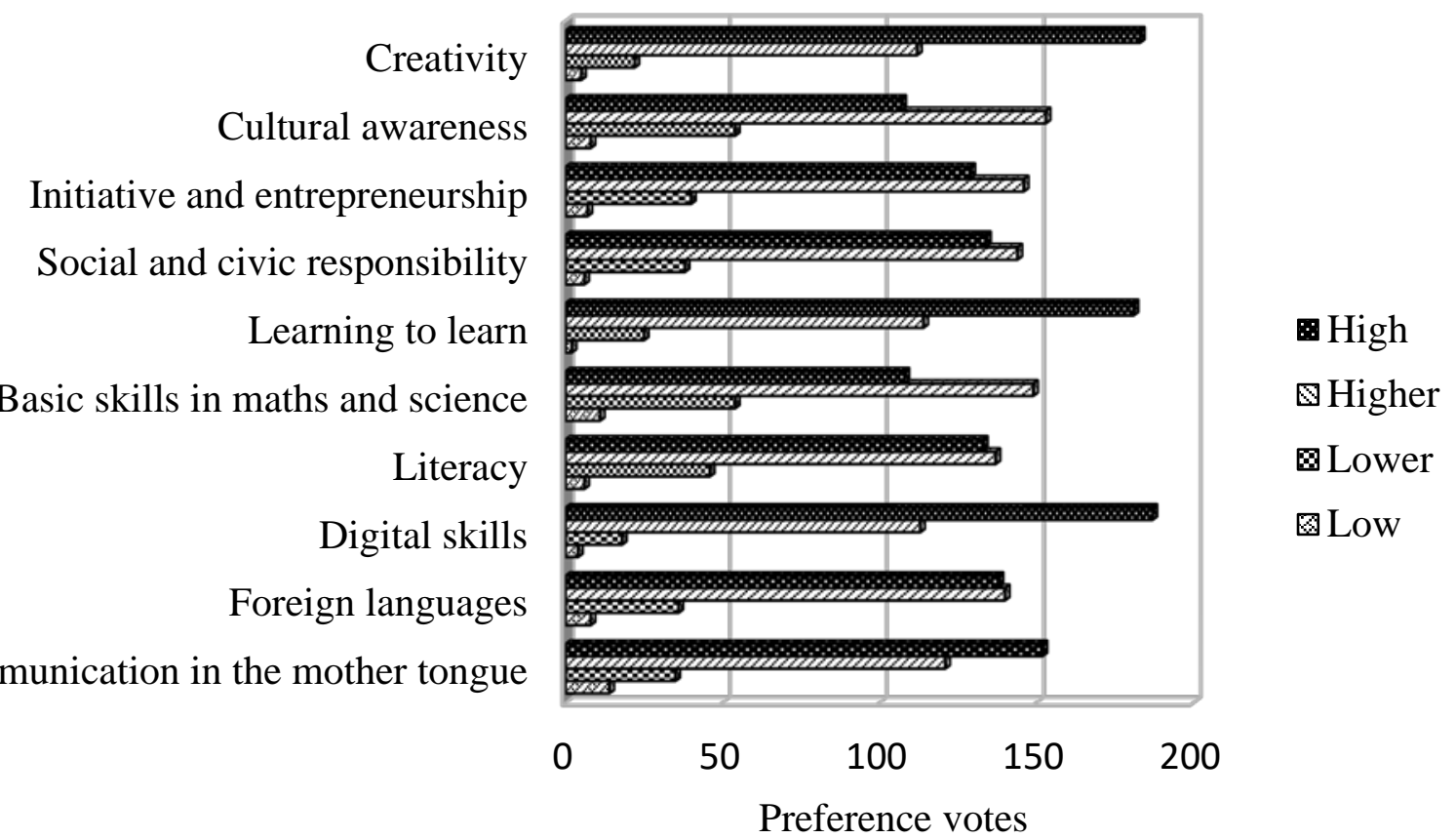

evaluation of the importance of the EU key competencies and skills to develop entrepreneurship (European Commission, 2017). The aim was to reach a wide spectrum of respondents from VET trainers to entrepreneurs and stakeholders with various fields of their specialisations. Totally, answers from 322 respondents have been collected. The second part of the survey consisted from 31 deep interviews gaining the views, experience and opinions of 19 VET trainers and also some engineers, entrepreneurs, personnel agency specialists, an ICT specialist and an international relations specialist. The questionnaire was evaluated through a spreadsheet with graphs for most survey items. All the interviews were transcript into the report (AROMA project consortium, 2018), in which only the country, the gender and professional background of the respondent are noted. Then, the common and overall views and suggestions were summarized.

\section{Results of Research}

Among the EU competencies most appreciated were digital skills, learning to learn (willing to learn) and creativity (see Figure 1). In connection with the competencies to promote entrepreneurship (Figure 2), some respondents pointed out that all are important and each of the selected competencies should be developed at some minimal level. The main obstacles for more extensive employing of the AR in training and education were the money (needed for hardware like glasses as well as for the software and experts developing the AR content). Also, it was pointed out the importance to keep the courses updated and follow the fast development of technology. As many teachers and trainers prefer to create the course materials themselves, it is crucial to train them and provide them with suitable motivating support to overcome starting difficulties when they make the first acquaintance with some technical details. 
Figure 2: Importance of selected competencies to develop entrepreneurship

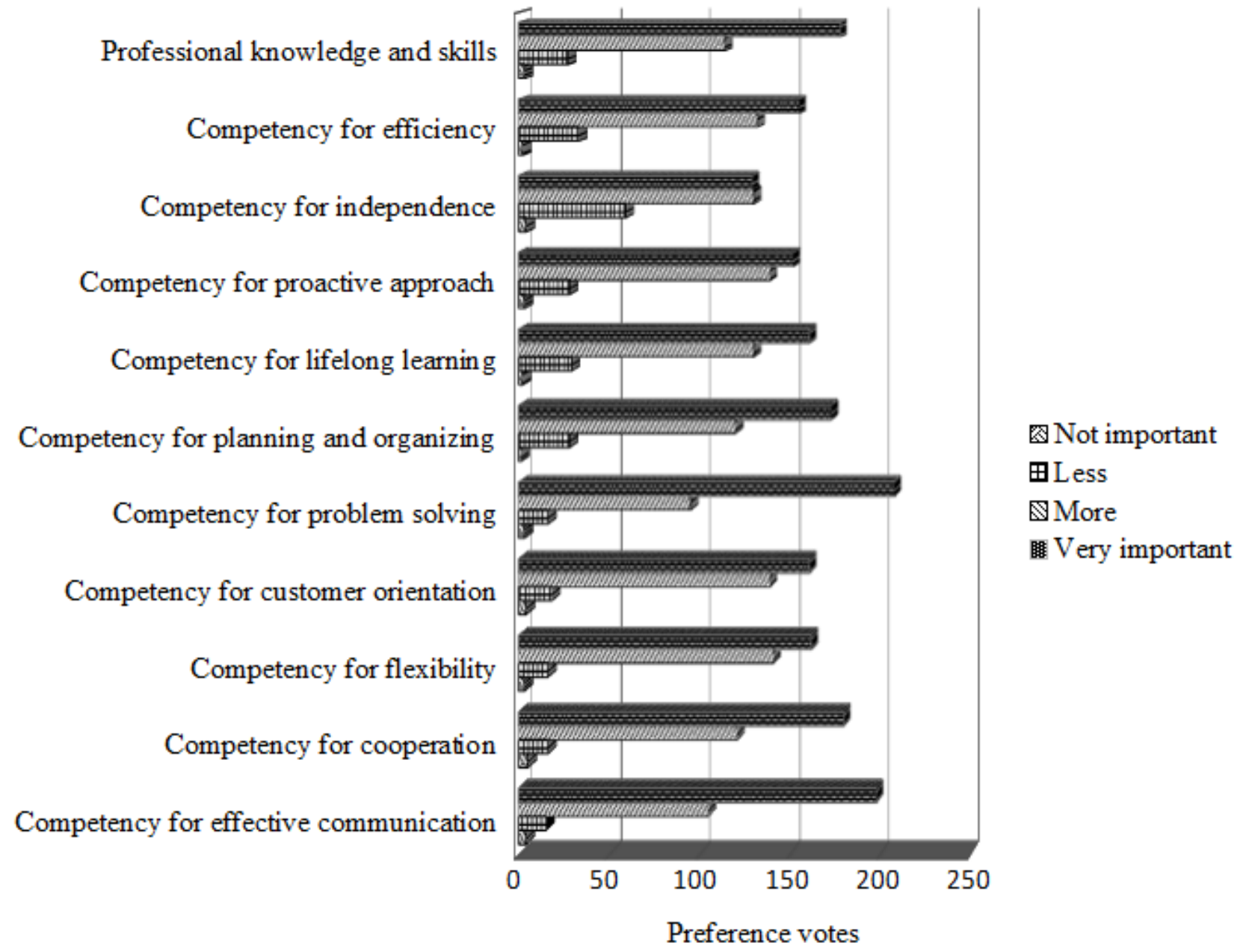

\section{Augmented reality in education and training}

Besides retail, marketing, tourism etc. the technology of AR gradually finds its way into education. The participants of our survey pointed out the following expected benefits of the technology:

- Explaining abstract and difficult concepts as the AR enables to render objects that are hard to imagine and turn them into 3D models.

- Engagement and interaction.

- Objects modelling: manual training, hand exercises, quiz solving etc. help earn a better knowledge of any lesson. AR apps for medical students may be one of the ways to learn human anatomy more deeply (see the example below).

- Students of technical faculties especially need practice and hands-on experience in their areas. Through interaction, AR features could help perform virtual training and acquire some experience.

- AR learning materials can be included in online learning systems and so may be accessed anytime, anywhere (often the connection to the internet is necessary).

- No special equipment is required - unlike virtual reality, augmented reality doesn't require any expensive hardware, often just our own smartphones. In Figure 3 we can see, that for the 
Figure 3: The applications used by our respondents in everyday life
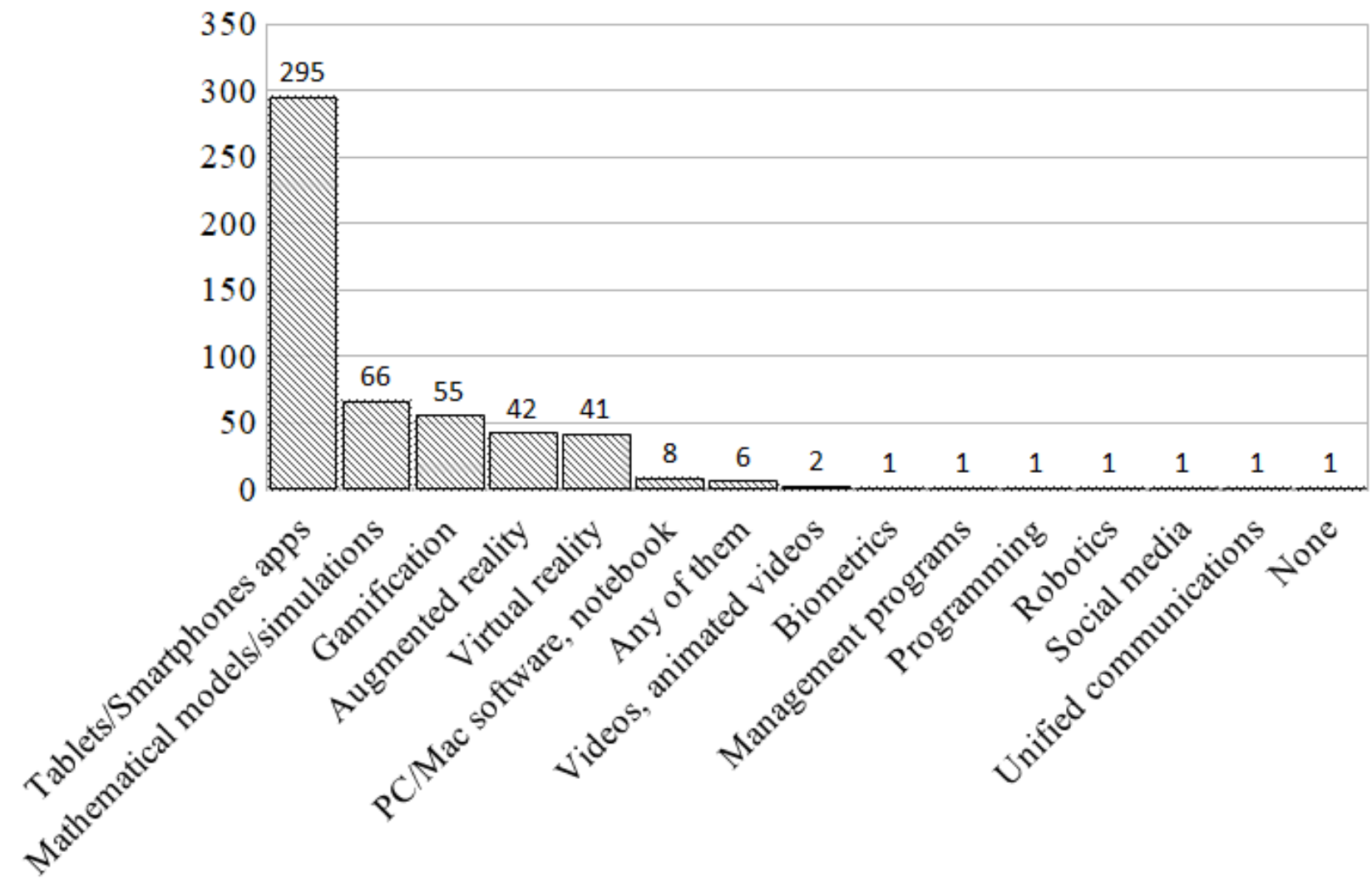

sample of our respondents, tablet/smartphone applications are undoubtedly mostly used among all available electronic or computer technologies.

- Many educators and trainers expect faster and more effective learning process. The AR in education helps students achieve better results through visualization and full immersion in the subject matter. Figure 4 illustrates that more than $90 \%$ of the participants in our survey think that AR technology might be useful in their jobs (including education and training).

- The AR should be in principle universally applicable to any level of education and training, be it learning games for kindergarten or on-the-job training.

Nowadays, it is very difficult for teachers to prepare the AR content themselves. Even the applications like HP reveal (https://www.hpreveal.com) or Augment (https://www.augment.com) are not freely available any longer and the development of AR content is still a domain for professional IT companies. Let us list a few examples of AR technology used in learning or with some educational potential:

- AR Circuits (http://arcircuits.com) enables to build and test realistic circuits without the expense, safety concerns, and inconveniences that come with real physical electric components (example video: https://youtu.be/OBPF-rG3ICY).

- An interactive gym wall (example video: https://youtu.be/dMExZl5jfAg) is a project of an elementary school in Quebec City for $4^{\text {th }}$-grade children for various training within physical education.

- Mondly AR (https://www.mondly.com/ar) is a language-learning app with an integrated ARbased virtual teacher to help users practice their skills as if they were in a real-life setting (example video: https://youtu.be/KmSN3-KG6cg). 
Figure 4: The answer to the question whether the AR technology might be useful in respondents work (business, education)

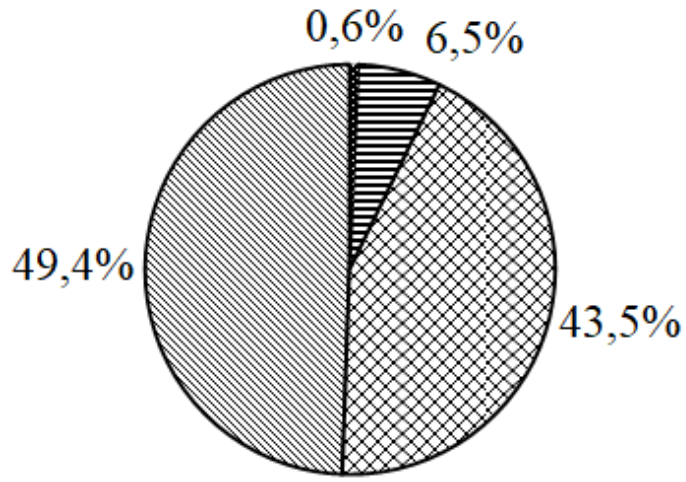

Definitely yes

Probably so

EProbably not

䀃Definitely not

- Visible Body (https://www.visiblebody.com/ar) added AR functionality to Human Anatomy Atlas so that users could place a virtual human organ or complete human body model on any flat surface, view it, or step through a virtual dissection (example video: https://youtu.be/Ljs3rL48uWU).

\section{Conclusions}

Though the AR technology gradually finds its way into business, education and common life, it can be still considered relatively unknown. Our respondents expect, that AR technology could accelerate training, increase its efficiency, make learning and training more dynamic and enabling to solve some problems faster. The most promising and effective ways how to promote the AR technology are sharing information online (e.g. via social media) and by presenting the best examples of how to use it profitably in practice. The training of teachers is very important for larger exploitation of the AR technology in education. Our survey also confirms the general importance of the key EU competencies and the selected competencies to develop entrepreneurship.

\section{Bibliography}

Akçayır, M., \& Akçayır, G. (2017). Advantages and challenges associated with augmented reality for education: A systematic review of the literature. Educational Research Review, 20, 1-11. doi: 10.1016/j.edurev.2016.11.002.

AROMA project consortium (2018). Status \& Foresight Report of European Augmented Reality Training Needs. Retrieved from: https://sites.google.com/view/ka2project/home.

Chang, S.-C., \& Hwang, G.-J. (2018). Impacts of an augmented reality-based flipped learning guiding approach on students' scientific project performance and perceptions. Computers \& Education, 125, 226-239. doi: 10.1016/j.compedu.2018.06.007.

Chen, C., \& Wang, C.-H. (2015). Employing Augmented-Reality-Embedded Instruction to Disperse the Imparities of Individual Differences in Earth Science Learning. Journal of Science Education and Technology, 1-13. doi: 10.1007/s10956-015-9567-3.

Chiu, J. L., DeJaegher, C. J., \& Chao, J. (2015). The effects of augmented virtual science laboratories on middle school students' understanding of gas properties. Computers \& Education, 85, 59-73. doi: 10.1016/j.compedu.2015.02.007.

European Commission (2017). Developing key competencies for all throughout life. Retrieved from: https://ec.europa.eu/education/sites/education/files/document-library-docs/factsheet-keycompetences-lifelong-learning_en.pdf. 
Fuchsova, M., \& Korenova, L. (2019). Visualisation in Basic Science and Engineering Education of Future Primary School Teachers in Human Biology Education Using Augmented Reality. European Journal of Contemporary Education, 8(1), 92-102. doi: 10.13187/ejced.2019.1.92.

Ibáñez, M.-B., \& Delgado-Kloos, C. (2018). Augmented reality for STEM learning: A systematic review. Computers \& Education, 123, 109-123. doi: 10.1016/j.compedu.2018.05.002.

Lamanauskas, V. (2008). The Augmented Reality Teaching / Learning Platform: Some Implications for the Present and Future. In.: Information and Communication Technology in Natural Science Education-2008 (Proceedings of International Scientific Conference, 28-29 November 2008). Siauliai: Siauliai University Press, p. 5-7. ISBN 978-9986-38-943-9.

Lincoln, J. (2018). Augmented reality Moon for astronomy lessons. The Physics Teacher, 56(7), 492493. doi: 10.1119/1.5055344.

Yip, J. et al. (2018). Improving quality of teaching and learning in classes by using augmented reality video. Computers \& Education. doi: 10.1016/j.compedu.2018.09.014.

\section{Acknowledgements}

The authors would like to thank all AROMA project partners, especially (in the alphabetical order of the institutions) to Amaya Beroiz (European Confederation of Young Entrepreneurs AISBL; Belgium/Spain), Sofia Tsiortou and Dimitrios Mylonas (IRIS ORGANISMOS KATARTISIS A.E., Greece), Emmanuel Francalanza and Stephanie Borg Cappello (MACDAC Engineering Consultancy Burreau, Ltd.; Malta), Itxaso Elizondo (Media Creativa 2020, S.L., Spain), Kenneth Sundin (SMEBOX, AB; Sweden), Ondřej Peterka and Michaela Patkanová (RPIC-ViP s.r.o.; Czech Republic), Teodora Daniela Chicioreanu and Paulina Spanu (Universitatea Politehnica din Bucuresti; Romania).

\section{Contact address}

Lukáš Richterek, Mgr. Ph.D., Katedra experimentální fyziky, Př́rodovědecká fakulta UP, 17. listopadu 1192/12, 77146 Olomouc, ČR, tel.: 00420585634 104, e-mail: lukas.richterek@upol.cz

Jan Ríha, Mgr. Ph.D., Katedra experimentální fyziky, Př́rodovědecká fakulta UP, 17. listopadu 1192/12, 77146 Olomouc, ČR, tel.: 00420585634 104, e-mail: jan.riha@upol.cz 